\title{
SLA Gene
}

National Cancer Institute

\section{Source}

National Cancer Institute. SLA Gene. NCI Thesaurus. Code C150075.

This gene is involved in the regulation of T-cell receptor and B-cell receptor signaling. 